\title{
Low Skill but High Volatility?
}

\author{
Claudia M. BUCH \\ CHRISTIAN PIERDZIOCH
}

\author{
CESIFO WORKING PAPER NO. 2665 \\ CATEGORY 7: MONETARY Policy AND InTERnATIONAL FinANCE \\ MAY 2009
}
An electronic version of the paper may be downloaded
- from the SSRN website: Www.SSRN.com
- from the RePEc website: $\quad$ www.RePEc.org
- from the CESifo website: $\quad$ www.CESifo-group.org/wp




\title{
Low Skill but High Volatility?
}

\begin{abstract}
Globalization may impose a double-burden on low-skilled workers. On the one hand, the relative supply of low-skilled labor increases. This suppresses wages of low-skilled workers and/or increases their unemployment rates. On the other hand, low-skilled workers typically face more limited access to financial markets than high-skilled workers. This limits their ability to smooth shocks to income intertemporally and to share risks across borders. Using cross-country, industry-level data for the years 1970 - 2004, we document how the volatility of hours worked and of wages of workers at different skill levels has changed over time. We develop a stylized theoretical model that is consistent with the empirical evidence, and we test the predictions of the model. Our results show that greater financial globalization and development increases the volatility of employment, and this effect is strongest for lowskilled workers. A higher share of low-skilled employment has a dampening impact.
\end{abstract}

JEL Code: F41.

Keywords: labor-market volatility, skill levels, financial globalization.

\author{
Claudia M. Buch \\ University of Tübingen \\ Department of Economics \\ Mohlstrasse 36 \\ Germany - 72074 Tübingen \\ claudia.buch@uni-tuebingen.de
}

\author{
Christian Pierdzioch \\ Macroeconomics and International \\ Economics \\ Department of Economics \\ Saarland University \\ Building C3 1 \\ P.O.B. 151150 \\ Germany - 66041 Saarbruecken
}

May 2009

Part of this paper has been written while Claudia Buch has been visiting the CES Institute in Munich and the National Bureau of Economic Research (NBER) in Cambridge, MA. The hospitality of these institutions as well as financial support from the Thyssen Foundation is gratefully acknowledged. We would like to thank Bernhard Boockmann, Alper Çenesiz, Michael Funke, Nico Zorell, and participants of the CESifo Area Conference on Macro, Money and International Finance (February 2009) for most helpful comments and discussions on an earlier draft. All errors and inconsistencies are solely in our own responsibility. 


\section{Motivation}

Globalization may impose a double-burden on low-skilled workers. On the one hand, the relative supply of low-skilled labor increases worldwide. This suppresses wages of low-skilled workers and/or increases their unemployment rates. On the other hand, low-skilled workers typically face more limited access to financial markets than high-skilled workers. This limits their ability to smooth shocks to income intertemporally and to share risks across borders. While a considerable amount of research effort has dealt with the implications of globalization for the relative job market performance of lowskilled workers (Feenstra and Hanson 2003, OECD 2007, Sitchinava 2008), the second potential burden of globalization has remained largely unexplored. Hence, the impact of financial globalization on the volatility of employment and of the income of low-skilled workers is the focus of this paper.

While a large literature has been concerned with output volatility, relatively little attention has been paid to the volatility of labor income. This literature shows that, until the outbreak of the recent financial crisis, there had been a decline in output volatility in many industrialized countries. The Great Moderation with regard to output volatility, however, has not necessarily been matched by a decline in employment volatility or in volatility at the household-level or firm-level. ${ }^{1}$ Comin et al. (2008) provide evidence for an increase in the volatility of employment in U.S. micro-data. In the United States, households at the lower end of the income distribution have also witnessed an increase in consumption volatility (Gorbachev 2007). Firm-level studies also show that the impact of increased competition on job stability

\footnotetext{
${ }^{1}$ See Davis and Kahn (2008) for a recent survey.
} 
differs for workers at different skill levels (OECD 2007). Finally, the ratio of consumption growth volatility to income growth volatility has increased during the recent period of globalization, particularly for emerging market economies (Kose et al. 2006). Differences with regard to financial market access across countries could be one reason for this finding.

Since the evolution of the volatility of wages and employment across industries, countries, and skill levels has remained largely unexplored, we use the EU KLEMS industry-level database to present descriptive statistics on the volatility of hours worked and of wages (Section 2). Focusing on industrylevel data allows analyzing longer-run trends in volatility across different countries while, at the same time, retaining information on differences across industries. Our data cover a maximum of 22 industries, 11 countries, and 35 years. The database has been constructed to analyze developments in productivity, and it also provides information on hours worked and wages across different skill categories. ${ }^{2}$ We use this database to compute employment and wage volatilities. We employ the multifactor residual model proposed by Pesaran (2006) to decompose macroeconomic and idiosyncratic components of volatility at the industry-level. In contrast to an unconditional volatility measure, we thus also use a conditional measure which accounts for macroeconomic factors.

We report three main stylized facts (see also Figures 1a and 1c). First, the volatility of hours worked of high-skilled workers has been higher than the volatility for medium-skilled workers. The volatility of hours worked for lowskilled workers lies in between. Second, while there has been a negative time

\footnotetext{
${ }^{2}$ See www.euklems.net. Timmer et al. (2007) provide a detailed description of the database and of methodological issues. Dew-Becker and Gordon (2007) use this database to study the link between employment growth and productivity.
} 
trend in the volatility of hours worked for medium-skilled workers, volatility for high- and low-skilled workers has tended to increase. Third, the unconditional volatility of wages has been very similar across skill groups. The conditional volatility of wages, in contrast, has been highest for high-skilled workers. Trends in the conditional volatility of wages, however, are similar across skill groups.

In Section 3, we develop a stylized stochastic dynamic general equilibrium model of a small open economy that is consistent with these stylized facts. In contrast to earlier literature, we assume that not all agents have access to financial markets. The economy is populated by optimizing households, who have access to bond markets, and rule-of-thumb households, who do not have access to bond markets (Galí et al. 2004, 2007, Amato and Laubach 2003, Bilbiie et al. 2008). Optimizing households represent high-skilled workers while rule-of-thumb households represent low-skilled workers. ${ }^{3}$ Empirical research strongly supports our assumption that some households are rule-ofthumb consumers. For example, Mankiw and Zeldes (1991) have found that a substantial proportion of U.S. households do not hold stocks, possibly because of the presence of credit constraints. Moreover, despite the substantial increase in the width and depth of financial markets since the early 1990s, households' financial assets remain highly concentrated among a relatively small share of the population. ${ }^{4}$

\footnotetext{
${ }^{3}$ Recent work in open economy macroeconomics relaxes the assumption that all agents have unrestricted financial-market access. In Levchenko (2005), domestic financial markets are underdeveloped, and access to international financial markets is restricted for some households. Leblebicioglu (2008) assumes borrowing frictions in a non-traded goods sector as well as limited access of owners of firms in the non-traded goods sector to international financial markets. The focus of both papers is on explaining the relatively high volatility of consumption in emerging markets. Alvarez et al. (2001) and Occhino (2004) have used the assumption that some households have limited access to financial markets to analyze monetary-policy issues in closed economies.
}

${ }^{4}$ See Lusardi and Mitchell (2007) for the United States and DIW (2007) for Germany. 
In Section 4, we test the predictions of the theoretical model by means of a formal regression analysis. One key prediction is that financial globalization should increase the volatility of hours worked for high-skilled households. Financial globalization and limited access to financial markets should also interact in shaping the volatility of hours worked. Finally, a higher volatility of TFP should increase the volatility of hours worked for high-skilled households. We find that a higher degree of financial integration indeed increases the volatility of hours worked. This effect is strongest for low-skilled workers. A larger share of rule-of-thumb households mitigates the effect of financial globalization on the volatility of hours worked, pointing to the significance of interaction effects. We also find that the magnitude of this interaction effect depends on workers' skill levels, as predicted by our theoretical model. The volatility of hours worked increases in the volatility of TFP, and this effect is strongest for higher-skilled workers, as expected. As regards the effects of TFP volatility on wages, we find similar responses across skill levels, in line with the predictions of the theoretical model.

In Section 5, we summarize our results and offer some concluding remarks.

\section{Descriptive Statistics}

What have been the trends in the volatilities of hours worked and of wages at the industry-level? While the volatility of output is well-documented, the stylized facts on the volatilities of hours worked and of wages are less well known, in particular as regards differences across skill groups. In order to set the stage for the theoretical analysis and for the more formal regression analysis to follow, we next document the basic patterns in the data that we want to explain. 


\subsection{Industry-Level Data}

We use industry-level data from the EU KLEMS database, which provides detailed growth-accounting information for European countries, Japan, and the United States. The database covers the period 1970-2005, and, thereby, allows analyzing trends in volatility of hours worked and wages over a relatively long time range. The database includes information on primary, secondary, and tertiary industries. It also gives consistent measures of hours worked and of wages, in addition to information on productivity and output. Hours worked can be split into high-, medium-, and low-skilled employment. Because workers at different skill levels are likely to differ in their access to financial markets and their ability to insure risks, this information is particularly valuable for our purpose.

- Please include Table 1 about here. -

Restricting the analysis to those countries which provide a breakdown of employment by skill levels gives a dataset for 22 industries and 11 countries. Details are given in the Data Appendix. Table 1 provides summary statistics. Given that information on incomes by skill levels start only in the 1980s for some countries, two panel datasets are created:

1. Panel 1 is "short and wide". It contains data on 11 countries (Austria, Denmark, Spain, Finland, France, Germany, Italy, Japan, Netherlands, United Kingdom, United States), 22 sectors, and 21 years (1982-2002). The total cross-section dimension is $N=241$.

2. Panel 2 is "long and narrow". It contains data on four countries (Germany, Italy, United Kingdom, United States) with information on 
hours worked by skill levels starting from the 1970s $(N=87)$. It runs from 1970 to $2004(T=35)$.

\subsection{Conditional and Unconditional Volatility}

In Figure 1, we present descriptive statistics for the median volatilities of hours worked and of wages across industries and countries. For comparison, we also provide information on the volatility of TFP. In order to isolate developments at the level of the individual industry from macroeconomic developments, we present conditional and unconditional measures of volatility. The unconditional volatility is the standard deviation of growth rates over a five-year time interval.

- Please include Figure 1 about here.

In order to compute conditional growth volatility, we need to distinguish an idiosyncratic, industry-specific component of growth from a macroeconomic, systemic component of growth. Not all of these macroeconomic factors are readily observable. Instead, some unobserved factors may affect all industries and countries. In order to account for observed and unobserved macroeconomic factors, the multifactor residual model developed by Pesaran (2006) is used. The logic of this model is as follows. Suppose that growth of hours worked or of wages is given by

$$
\hat{y}_{i t}=\alpha_{i}^{\prime} d_{t}+\beta_{i}^{\prime} x_{i t}+\epsilon_{i t}
$$

where $i=1,2, \ldots, N$ is the number of industry-country pairs and $t=1,2, \ldots, T$ is the number of years. Equation (1) states that industry-level growth depends on a $k \times 1$ vector of observable macroeconomic factors, $d_{t}$, and a vector 
of observed industry-specific factors, $x_{i t}$. The errors are assumed to have a multifactor structure:

$$
\epsilon_{i t}=\gamma_{i}^{\prime} f_{t}+u_{i t},
$$

where $f_{t}$ is an $m \times 1$ vector of unobserved macroeconomic factors, and $u_{i t}$ are the industry-specific (idiosyncratic) errors, which are assumed to be distributed independently of $d_{t}$ and $x_{i t}$. The unobserved factors can be correlated with $d_{t}$ and $x_{i t}$, hence the industry-specific factors are modeled according to

$$
x_{i t}=A_{i}^{\prime} d_{t}+\Gamma_{i}^{\prime} f_{t}+\nu_{i t},
$$

where $A_{i}$ and $\Gamma_{i}$ are factor-loading matrices, and $\nu_{i t}$ are components of $x_{i t}$ which are independent from macroeconomic factors. The heterogeneous factor loadings, $\alpha_{i}$ and $\gamma_{i}$, can be estimated consistently when both $N$ and $T$ are large.

In most applications, the interest is in the slope coefficient, $\beta_{i}$, in Equation (1). Instead, we are interested in the term, $u_{i t}$, which gives conditional growth in industry $i$ which is uncorrelated with observed and unobserved macroeconomic factors. The key challenge is to isolate developments at the industry-level from aggregate developments while taking into account that some of the macroeconomic factors that affect all industries are unobserved. In order to isolate the factors $d_{t}$ and $f_{t}$ from industry-specific variables, $x_{i t}$, the growth rates of hours worked and wages are thus regressed on observed and unobserved macroeconomic factors. These regressions are run separately for each of the cross-sections, and the residuals from these regressions are retained. 
The multifactor residual model is applied to the "long and narrow" panel, including four observed macroeconomic factors that affect aggregate volatility (growth in GDP per capita, inflation, energy prices, and trade openness). Following Pesaran (2006), the unobserved macroeconomic factors can be proxied through the sample means of industry-specific variables. We use mean output growth, mean TFP growth, and the mean change in relative prices across industries. The dependent variable is the log growth rate of hours worked or wages.

Because the multifactor residual model requires sufficiently long time series, it cannot be applied to the "short and wide" panel. For this panel, the conditional, industry-specific growth component is obtained by running a pooled regression of the change in log wages and hours worked on a full set of timecountry and time-industry fixed effects. The purpose of these regressions is to demean growth rates and to purge them from macroeconomic developments affecting all industries and countries. The residuals of these regression equations are the conditional, industry-specific growth components.

With a measure of conditional growth of hours worked and of wages at hand, the rolling average standard deviations for conditional and unconditional growth rates over a five year window are computed as:

$$
\sigma\left(\hat{u}_{i t}\right)=\frac{1}{5} \sqrt{\sum_{k=0}^{4}\left(\hat{u}_{i, t+k}-\overline{\hat{u}}_{i}\right)^{2}},
$$

where $\hat{u}_{i t}$ is the residual, industry-specific component of growth, and $\overline{\hat{u}}_{i}$ is the corresponding mean. Equation (4) is applied to the volatility of wages and of hours worked at different skill levels. In order to check the robustness of the regression results reported below, a quasi-panel of non-overlapping volatilities is used as well. 


\subsection{Volatility of Hours Worked and Wages}

Figure 1 plots volatility, distinguishing the "short and wide" Panel 1 (Figures $1 \mathrm{a}-1 \mathrm{~b})$ from the "long and narrow" Panel 2 (Figures 1c-1d). For each of these panels, the conditional and unconditional volatilities of hours worked and wages (Figures 1a and 1c) and of TFP (Figures $1 \mathrm{~b}$ and 1d) are plotted. We also present evidence on the time trends in employment shares and in debt market integration (Figure 1e). These variables will be used as regressors in Section 4 below, and they are key parameters of the theoretical model in Section 3.

Figures 1a and 1c show some distinct differences in the level of volatility of hours worked by skill group. While, in terms of hours worked, medium-skilled employment is the least volatile employment category throughout (0.036 in the "short and wide" panel, see also Table 1), high- and low-skilled employment are relatively volatile (0.061 and 0.050 , respectively). The differences between high- and low-skilled employment in the "long and narrow" panel are not that large.

Time trends in volatility of hours worked differ as well across skill groups. For medium-skilled workers, there has been a trend decline in volatility. Such evidence for a Great Moderation in volatility of hours worked is much less evident for the other skill groups. These differences in the time trends of volatility of hours worked could be the result of different responses to TFP volatility and to international financial integration. As shown by Figure 1b, the volatility of TFP has been on a trend decline in the "short and wide" panel, in particular since the mid-1970s. In the "long and narrow" panel, there is some evidence for an increase in TFP volatility in recent years (Figure 1d). The degree of debt market integration has increased throughout (Figure 
1e). Figure 1e also shows different time patterns of employment shares, the most important trend being the decline of low-skilled employment.

As regards the volatility of wages, the first observation that can be taken from Figures $1 \mathrm{a}$ and $1 \mathrm{c}$ is that the unconditional wage volatility has been very similar across skill groups (0.108). There has been a Great Moderation in wage volatility in the 1980s and 1990s, which has partly reversed in recent years. Conditional wage volatilities again bring out differences across skill groups. Wages of medium-skilled workers respond most to macroeconomic factors, and conditional wages of medium-skilled workers are thus the least volatile. The general trends in the conditional volatility of wages, however, are similar across skill groups. Generally, there is evidence for a downward trend in conditional wage volatility.

Finally, it is important to note the differences in volatility levels for wages and hours worked. The unconditional volatility of wages $(0.108)$ has been much higher than the unconditional volatility of hours worked (0.028). Conditional volatilities of wages and hours worked, in contrast, are much more similar (0.026 versus 0.021$)$ (Table 1$)$.

In sum, this section shows three main stylized facts. First, the volatility of hours worked of high-skilled workers has been higher than the volatility for medium-skilled workers. The volatility of low-skilled workers lies in between. Second, the unconditional volatility of wages has been very similar across skill groups. The conditional volatility of wages has been highest for highskilled workers, but the general trends in the conditional volatility of wages have been similar. Third, while there has been a negative time trend in the volatility of hours worked for medium-skilled workers, volatility of high- and low-skilled workers has tended to increase. 


\section{Theory}

How does financial globalization affect the volatility of hours worked and of wages? How is this link affected by the presence of workers with different skill levels? In order to organize our thinking about these questions, we analyze a dynamic general equilibrium model which allows studying the link between financial globalization and labor market volatility.

We model financial globalization in two ways. First, we assume that workers at different skill levels differ with regard to their access to financial markets. Second, we assume that buying and selling financial assets across borders entails transaction costs, which affect the volume of cross-border capital flows. Distinguishing these aspects of financial integration is important for our empirical analysis below. In our regression analysis in Section 4, the employment shares of low-skilled workers as proxies for limited market access will vary across industries and countries. The degree of debt market integration as a proxy for transaction costs, in contrast, will differ across countries. Empirically, we will also allow for differences in financial development across countries.

Our dynamic general equilibrium model is broadly consistent with the stylized facts laid out in Section 2. In particular, our model implies that the volatility of wages is the same across skill groups, and that the volatility of hours worked is higher for high-skilled households than for low-skilled households. The model also has empirically testable predictions regarding the links between financial globalization and the share of low-skilled workers in the workforce, on the one hand, and the volatilities of hours worked and wages, on the other hand. We shall analyze the predictions of the model in Section 4 using the data presented in Section 2. 
We consider a stylized small open economy populated by a large number of infinitely-lived households of total measure unity and a continuum of perfectly competitive firms. A proportion, $0<1-\tilde{\lambda}<1$, of households has access to financial markets. Households with access to financial markets maximize their expected present-discounted value of utility. To this end, they can invest in internationally traded one-period riskless bonds. The remaining proportion, $\tilde{\lambda}$, of households does not have access to financial markets. These households are rule-of-thumb consumers who consume, in every period of time, their labor income. We associate the type of household with its skill level. Hence, optimizing households are high-skilled while rule-ofthumb households are low-skilled. In contrast to the empirical analysis, we thus simply the analysis and abstract from workers with medium skill-levels.

\subsection{Optimizing Households}

Optimizing, high-skilled households maximize the intertemporal utility function, $\mathcal{V}$ :

$$
\mathcal{V}=\mathbb{E}_{0} \sum_{t=0}^{\infty} \beta^{t} u\left(c_{t}^{o}, h_{t}^{o}\right),
$$

where $\mathbb{E}_{t}$ denotes the conditional expectations operator, $0<\beta<1$ denotes a discount factor, $u\left(c_{t}^{o}, h_{t}^{o}\right)$ denotes a period-utility function, and $c_{t}^{o}$ and $h_{t}^{o}$ denote consumption and hours worked, where the superscript " $o$ " denotes optimizing, high-skilled households. Following Galí et al. (2004) and Bilbiie et al. (2008), we assume that the period-utility function is of the form $u\left(c_{t}^{o}, h_{t}^{o}\right)=\frac{1}{1-\sigma}\left(c_{t}^{o}\left(1-h_{t}^{o}\right)^{\nu}\right)^{1-\sigma}$, where $\sigma$ and $\nu$ are positive parameters. ${ }^{5}$

\footnotetext{
${ }^{5} \mathrm{~A}$ sufficient condition for saddlepath stability is $\sigma \geqslant 1$.
} 
Optimizing households maximize Equation (5) subject to the following sequence of budget constraints:

$$
d_{t+1}^{o}=(1+\bar{r}) d_{t}^{o}-w_{t} h_{t}^{o}+c_{t}^{o}+\frac{\psi}{2}\left(d_{t+1}^{o}-\tilde{d}\right)^{2}
$$

where $d_{t}^{o}$ denotes optimizing households' foreign debt measured in terms of one-period real bonds, and $w_{t}$ denotes the real wage determined in a perfectly competitive labor market. In line with the results reported in Section 2 , the real wage is the same for optimizing households and rule-of-thumb households. In order to focus on the effects of globalization on labor market volatility, we deliberately abstract from effects of globalization on relative wages. The parameter $\bar{r}$ denotes the positive and constant real interest rate. We assume a small open economy, hence the interest rate exogenously given. The final term on the right-hand side of Equation (6) captures portfolio adjustment costs. Portfolio adjustment costs are a measure of the degree of financial globalization. ${ }^{6}$ The parameters $\psi>0$ and $\tilde{d}$ define the adjustmentcost function, where $\tilde{d}$ denotes foreign debt in the non-stochastic steady state.

The first-order conditions for optimizing households' utility-maximization problem with respect to $c_{t}^{o}, h_{t}^{o}$, and $d_{t+1}^{o}$ are given by

$$
\begin{aligned}
& \frac{\partial u_{t}^{o}}{\partial c_{t}^{o}}-\lambda_{t}=0, \\
& \frac{\partial u_{t}^{o}}{\partial h_{t}^{o}}+\lambda_{t} w_{t}=0, \\
& -\beta(1+\bar{r}) \mathbb{E}_{t} \lambda_{t+1}+\lambda_{t}\left(1-\psi\left(d_{t+1}^{o}-\tilde{d}\right)\right)=0,
\end{aligned}
$$

\footnotetext{
${ }^{6}$ In addition, the portfolio adjustment costs make the non-stochastic steady state of the model stationary (Schmitt-Grohé and Uribe 2003).
} 
where $\lambda_{t}$ denotes the Lagrange multiplier on Equation (6). The first two first-order conditions are the households' intratemporal optimality conditions for optimal consumption and labor supply. The third first-order condition gives the intertemporal optimality condition for foreign debt. High-skilled households can borrow and lend internationally to smooth their consumption profile over time and to cushion their consumption against fluctuations in income. We assume that the usual transversality condition holds.

\subsection{Rule-of-Thumb Households}

Rule-of-thumb, low-skilled households do not have access to financial markets, and they simply consume their labor income. They maximize the period-utility function, $u\left(c_{t}^{r}, h_{t}^{r}\right)$, which has the same parameters and functional form as the period-utility function of optimizing, high-skilled households. This assumption allows focusing on the implications of differential access to financial markets. Rule-of-thumb households maximize utility subject to the budget constraint

$$
c_{t}^{r}=w_{t} h_{t}^{r}
$$

The superscript " $r$ " denotes rule-of-thumb, low-skilled households. The firstorder conditions for their utility-maximization problem imply (Galí et al. 2004):

$$
\begin{aligned}
h_{t}^{r} & =\frac{1}{1+\nu}, \\
c_{t}^{r} & =\frac{1}{1+\nu} w_{t} .
\end{aligned}
$$


The consumption of rule-of-thumb, low-skilled households is proportional to the real wage, and the hours worked by rule-of-thumb households are constant over time. Consistent with the stylized facts presented in Section 2, the volatility of hours worked of optimizing, high-skilled households thus exceeds the volatility of hours worked of rule-of-thumb, low-skilled households. Note that, as rule-of-thumb households lack any insurance mechanism, their consumption is fully exposed to shocks affecting wages.

\section{$3.3 \quad$ Firms}

Firms produce output, $y_{t}$, according to the production function $y_{t}=A_{t} h_{t}$, where $h_{t}$ denotes aggregate hours worked, and $A_{t}$ denotes productivity. Profit maximization implies that the dynamics of the real wage, $w_{t}$, are entirely determined by the dynamics of productivity. Productivity evolves according to the autoregressive process

$$
\hat{A}_{t}=\rho \hat{A}_{t-1}+\epsilon_{t},
$$

where $0 \leq \rho<1$. A hat denotes percentage deviations from the nonstochastic steady state, and $\epsilon_{t}$ denotes a serially uncorrelated mean-zero shock with constant variance, $\sigma_{\epsilon}^{2}$. 


\subsection{Aggregation}

Aggregate consumption, aggregate hours worked, and aggregate foreign debt are given by

$$
\begin{aligned}
c_{t} & =\tilde{\lambda} c_{t}^{r}+(1-\tilde{\lambda}) c_{t}^{o}, \\
h_{t} & =\tilde{\lambda} h_{t}^{r}+(1-\tilde{\lambda}) h_{t}^{o}, \\
d_{t} & =(1-\tilde{\lambda}) d_{t}^{o} .
\end{aligned}
$$

\subsection{Steady State}

We consider a symmetric non-stochastic steady-state characterized by $\bar{c} r=$ $\bar{c} \bar{c}=\bar{c}$ and $\overline{h^{o}}=\bar{h}^{r}=\frac{1}{1+\nu}$. A bar denotes a variable in the steady state. Optimizing households' first-order conditions imply $\beta=\frac{1}{1+\bar{r}}$. Because $\bar{d}^{o}=$ $\tilde{d}$, the budget constraint of optimizing households implies $-\bar{r} \tilde{d}=-\bar{w} \bar{h}+\bar{c}$. The budget constraint of rule-of-thumb households then gives $\tilde{d}=\bar{d}^{o}=\bar{d}=$ 0 . Finally, upon setting $\bar{A}=1$, symmetry implies $\bar{c}=\bar{y}=\frac{1}{1+\nu}$.

\subsection{Loglinearized Equations}

The production function implies $\hat{y}_{t}=\hat{A}_{t}+\hat{h}_{t}$, and profit-maximization yields $\hat{w}_{t}=\hat{A}_{t}$. The budget constraint of rule-of-thumb households gives $\hat{c}_{t}^{r}=\hat{w}_{t}$. Optimizing households' budget constraint, expressed in terms of aggregates, can be written as

$$
\hat{d}_{t+1}=(1+\bar{r}) \hat{d}_{t}-\frac{1+\nu}{\nu} \hat{h}_{t}
$$


where we define $\hat{d}_{t}=\frac{d_{t}}{\bar{c}}$. Optimizing households' first-order conditions yield $-w_{t} \frac{\partial u\left(c_{t}^{o}, h_{t}^{o}\right)}{\partial c_{t}^{o}}=\frac{\partial u\left(c_{t}^{o}, h_{t}^{o}\right)}{\partial h_{t}^{o}}$, and aggregation gives

$$
\hat{w}_{t}-\frac{1}{\nu} \hat{h}_{t}=\hat{c}_{t}
$$

Upon using Equation (18) and the result $\hat{c}_{t}^{r}=\hat{w}_{t}$, the first-order condition $\frac{\partial u\left(c_{t}^{o}, h_{t}^{o}\right)}{\partial c_{t}^{o}}=\lambda_{t}$ can be aggregated to give

$$
-\sigma \hat{c}_{t}+\frac{1}{1-\tilde{\lambda}}\left(\tilde{\lambda} \frac{\sigma}{\nu}+\sigma-1\right) \hat{h}_{t}=\hat{\lambda}_{t}
$$

Finally, optimizing households' intertemporal first-order condition, when combined with Equations (13), (18), and (19), is given by

$$
\left(\frac{\sigma}{\nu}+\sigma-1\right) \mathbb{E}_{t}\left(\hat{h}_{t+1}-\hat{h}_{t}\right)=\sigma(\rho-1)(1-\tilde{\lambda}) \hat{A}_{t}-\frac{\psi}{1+\nu} \hat{d}_{t+1}
$$

\subsection{Model Predictions}

Equation (20) shows that a positive productivity shock leads, at the aggregate level, to a negative expected growth rate of hours worked. A negative expected growth rate of hours worked requires that, in the aftermath of a productivity shock, hours worked increase above their steady-state value. Because hours worked by rule-of-thumb, low-skilled households do not change, optimizing, high-skilled households work harder. These households work harder because the shock entails an increase in the real wage.

It follows from Equation (20) that a large proportion of rule-of-thumb, lowskilled households, $\hat{\lambda}$, cushions the effect of a productivity shock on the dynamics of hours worked. When only rule-of-thumb, low-skilled households 
populate the economy, the expected rate of change of hours worked becomes zero because hours worked by rule-of-thumb, low-skilled households are constant. As a result, our model predicts that financial globalization, when measured in terms of a decrease in the proportion of rule-of-thumb consumers, should lead to an increase in the volatility of hours worked.

Equation (20) further shows that financial globalization, when measured in terms of a reduction of transaction costs, $\psi$, mitigates the impact of foreign debt on the dynamics of hours worked. Hours worked respond to foreign debt because deviations of foreign debt from its steady-state value entail transaction costs. For example, when foreign debt is below its steady-state value, optimizing households work less hard such that foreign debt returns to its steady-state value and transaction costs decrease.

Equation (17) implies that productivity and foreign debt move in opposite directions. A positive productivity shock leads to an intertemporal substitution of labor because firms pay higher wages. Optimizing households substitute out of leisure. Their income increases and intertemporal consumption smoothing then implies that optimizing households' consumption does not move one-to-one with income. As a result foreign assets increase (i.e., foreign debt decreases).

At the same time, as shown by Equation (20), foreign debt and hours worked move in the same direction whenever households must pay transaction costs. Hence, combining Equations (20) and Equation (17) yields the result that transaction costs mitigate the effect of a productivity shock on hours worked. Financial globalization, when measured in terms of a reduction in transaction costs, thus should give rise to higher volatility of hours worked. 
Because the volatility of hours worked by rule-of-thumb, low-skilled households is zero, hours worked by optimizing, high-skilled households should become more volatile in the process of financial globalization. The impact of financial globalization on the volatility of hours worked thus should differ for households at different skill levels.

Equations (17) and Equation (20) further imply that the magnitude of the increase in volatility of hours worked brought about by a reduction in transaction costs (that is, the change in the slopes of the curves as one moves from right to left) is an inverse function of the proportion of rule-of-thumb, lowskilled households. A large proportion of rule-of-thumb, low skilled households dampens the effect of a productivity shock on hours worked and on foreign debt. Small fluctuations in foreign debt entail small transaction costs. The relative importance of changes in the parameter $\psi$ for the volatility of hours worked thus tends to be smaller when the proportion of rule-of-thumb, low-skilled households is large than when this proportion is small. It follows that, as concerns the volatility of hours worked, there should be interaction effects between financial globalization and the proportion of rule-of-thumb, low-skilled households.

Finally, one may ask whether higher volatility is the price households have to pay for financial globalization. While financial globalization results in higher volatility of hours worked for optimizing, high-skilled households, their consumption volatility decreases. The fall in their consumption volatility mirrors the improvement in risk-sharing and consumption-smoothing possibilities brought about by financial globalization. For the economy as a whole, risk-sharing opportunities may improve due to lower transaction costs or a fall in the proportion of rule-of-thumb, low-skilled households. 
Concerning the volatility of aggregate consumption, it is important to note that the volatility of consumption of rule-of-thumb, low-skilled households is entirely determined by the volatility of productivity. It follows that changes in the volatility of aggregate consumption, for a given $\tilde{\lambda}$, reflect changes in the volatility of consumption of optimizing, high-skilled households.

While the volatility of consumption may be considered a more direct measure of volatility facing private households, we do not use consumption data in our regression analysis for two reasons. First, reliable information on the consumption of workers by industry and across different countries is, to the best of our knowledge, not available. Second, volatility of wage income can be considered a proxy for the volatility of consumption, in particular for ruleof-thumb households which do not have access to credit markets to smooth consumption over time.

\section{Regression Analysis}

In this section, we conduct a formal regression analysis to test the main predictions of our theoretical model described in Section 3. To this end, we use the dataset introduced in Section 2. As the dependent variable, we use the conditional volatility of hours worked (or of wages) in each industrycountry pair $i$ and year $t$ :

$$
\sigma\left(\hat{u}_{i t}\right)=\alpha_{i t}+\beta_{1} X_{i t}+T_{t}+e_{i t}
$$

where $\sigma\left(\hat{u}_{i t}\right)$ denotes the volatility of hours worked, and $\alpha_{i t}$ denote countryindustry-fixed effects. We also include a full set of time fixed effects, $T_{t}$. These account for business cycle effects such as changes in monetary policy 
and other aggregate shocks affecting all countries and industries alike. $e_{i t}$ denotes the error term.

We estimate the regression equation specified in Equation (21) separately for each skill group (high-skilled, medium-skilled, low-skilled). The list of explanatory variables, $X_{i t}$ contains the volatility of TFP in each industrycountry pair because fluctuations in our theoretical model are driven by shocks to productivity. The list also includes the share of cross-border debt over GDP and the share of cross-border assets and liabilities over GDP as measures of financial globalization, which vary across countries. We include interaction terms that capture how financial globalization interacts with the proportion of rule-of-thumb households. We use the proportion of low-skilled workers in the total workforce in an industry as a proxy. Finally, we account for the state of development of the domestic financial system by including the ratio of deposit money banks' assets over GDP.

The regression results are reported in Table 2. We report results for two specifications of the dependent variable, using the 5-year moving average of volatility and a quasi-panel that features non-overlapping observations of volatility. Our results are as follows (expected signs in brackets):

- Volatility of TFP(+): The theoretical model predicts that the volatility of TFP should have a positive effect on the volatility of hours worked of high-skilled workers. The regression results are in line with this prediction. Volatility of TFP exerts a positive effect on the volatility of hours worked. Point estimates also decline in the skill level, i.e., we find the highest point estimates for high-skilled workers and the lowest for low-skilled workers. For low-skilled workers, TFP volatility is 
insignificant in both regression models, in line with the predictions of our theoretical model.

- Financial globalization $(+)$ : The theoretical model predicts that integration of international debt markets should result in a higher volatility of hours worked, in particular for high-skilled workers. Higher crossborder assets and liabilities (debt) indeed have a positive impact on the volatility of hours worked. Interestingly though, these results are mostly driven by employment of low-skilled workers.

- Interaction terms (-): The theoretical model predicts that the volatility of hours worked brought about by integration of international debt markets becomes smaller as the proportion of rule-of-thumb, low-skilled workers increases. Our regression results in fact confirm this prediction - the interaction terms between debt market integration and the proportion of low-skilled workers in an industry are negative and significant. The point estimates are similar across skill levels when we use a 5-year rolling average. In the quasi-panel, the point estimate is more than twice as large in absolute value for high-skilled workers than for low-skilled workers, which is in line with the predictions of our model.

- Domestic financial development (+): The ratio of domestic money banks's assets over GDP is often used as a proxy for the state of development of the domestic financial system. We expect a positive sign since a more developed financial system should be associated with lower transactions costs. Consistent with these expectations, we find a positive and significant effect.

We have run similar regressions using the volatility of wages instead of hours worked as the dependent variable (Table 3). In line with the predictions 
of our theoretical model, we find a positive and significant impact of TFP volatility with roughly similar point estimates across skill groups. Also, greater financial globalization leads to more wage volatility with, again, similar effects across skill groups. This volatility-enhancing effect of financial globalization is insignificant in the quasi-panel model. The interaction terms between financial globalization and the proportion of low-skilled workers are insignificant in the majority of cases. Domestic financial development has a negative impact.

In order to check the robustness of our regression results, we also have reestimated the empirical model excluding the United States, including measures for trade, and replacing the measure of debt market integration with a measure of total cross-border financial assets. Excluding the United States as a country for the which the small-country-assumption of our theoretical model is violated gives qualitatively similar results. Measures for trade openness, which are included to address the fact that trade and financial integration often move in parallel, are insignificant. However, since we have information on trade by industries only for the manufacturing sector, the sample size also decreases substantially. Finally, measures for total crossborder assets give qualitatively the same results as measures for cross-border debt assets.

Finally, we have used a number of de facto measures of financial integration in the form of capital controls. Schindler (2008), for instance, provides new evidence based on the IMF's Annual Report of Exchange Arrangements and Restrictions. However, none of these measures gave reasonable results, neither being used directly as regressors nor as instruments in regressions using de factor measures of financial openness in the form of actual capital flows. This is partly due to the fact the the time series evidence has been 
relatively short. Partly, however, it also seems to be due to the fact is that what matters for risk-sharing is the actual, not the legal degree of openness.

\section{Summary and Concluding Remarks}

The impact of globalization and in particular trade integration for relative wages across skill groups has been extensively analyzed in earlier literature. We have studied the impact of financial globalization on workers at different skill levels from a different angle. More specifically, we have studied the implications of the process of financial globalization for the volatility of hours worked and of wages of workers at different skill levels. Based on a large industry-level dataset, we have identified general patterns in the unconditional and conditional volatilities of hours worked and of wages across time and across skill groups.

Stylized facts show that employment of high-skilled workers is the most volatile, that employment volatility of high- and low-skilled workers has increased while volatility of medium-skilled workers has decreased, and that volatility of wages has been fairly similar across skill groups

We have then developed a dynamic general equilibrium model driven by technology shocks that is consistent with the general patterns in the data. We have used the model to trace out the implications of financial globalization and limited access to financial markets by low-skilled workers for the volatility of hours worked and wages across skill groups. The model predicts that financial globalization increases the volatility of employment for high-skilled workers. Moreover, financial globalization and limited financial market access interact in shaping employment volatility. For households 
with access to financial markets, financial globalization also brings about improved risk-sharing possibilities.

Finally, we have tested the predictions of the model concerning the volatility of employment and wages by means of a formal regression analysis. We find that, in line with the predictions of our theoretical model, a higher volatility of TFP increases the volatility of hours worked (for high- skilled workers) and of wages (across all skill groups). Also in line with our model, a higher degree of financial globalization and development increases the volatility of hours worked. The impact of financial globalization on the volatility of hours worked is weaker if the proportion of low-skilled workers in the workforce of a particular industry is large. Consistent with the predictions of our theoretical model, we thus find that the volatility of hours worked depends negatively on an interaction effect between financial globalization and the proportion of low-skilled workers in the workforce. The intuition behind this result is that a lower share of low-skilled, rule-of-thumb workers lowers the impact of international financial integration.

Not surprisingly, our theoretical model cannot explain all patterns in the data. For identifying fruitful avenues for future research, the dimensions along which our model does not fit the data are as important as the dimensions along which the data match the predictions of the model. For example, our regression analysis has shown that financial globalization tends to increase the volatility of hours worked of low-skilled workers. Financial globalization may thus impose a double-burden on rule-of-thumb, low-skilled workers by making their hours worked and, via the budget constraint, their consumption more volatile. In the theoretical model, financial globalization can affect the volatility of consumption of rule-of-thumb, low-skilled workers 
only through the volatility of wages, which, by construction, moves one-toone with the volatility of productivity. Our model, therefore, predicts a zero correlation between the volatility of wages and financial globalization. Our regression analysis, in contrast has shown that the volatility of wages tends to be positively correlated with financial globalization. When interpreted in terms of our theoretical model, this positive correlation may indicate that financial globalization affects the volatility of TFP.

The results reported in this paper thus can only be viewed as a first step towards a deeper exploration of the implications of financial globalization for the volatility of hours worked and wages and, more generally, for the volatility of other important labor market indicators. More research is required to fully understand whether financial globalization imposes a double burden on lowskilled workers. For example, in order to derive more empirically testable implications, our theoretical model could be extended to include capital and investment, labor market frictions, and segmented labor-markets for lowskilled and high-skilled workers. It would also be interesting to analyze a multi-sector model in which high-skilled workers and low-skilled workers are concentrated in different industries. We plan to consider some of these extensions in our own future research. 


\section{References}

Alvarez, F., R.E. Lucas, and W.E. Weber (2001). Interest Rates and Inflation. American Economic Review (Papers and Proceedings) 91: $219-225$.

Amato, J.D., and T. Laubach (2003). Rule-of-thumb behaviour and monetary policy. European Economic Review 47:791-831.

Bilbiie, F.O., A. Meier, and G.J. Müller (2008). What Accounts for the Changes in U.S. Fiscal Policy Transmission? Journal of Money, Credit, and Banking 40: 1439-1469.

Comin, D., E.L. Groshen, and B. Rabin (2008). Turbulent Firms, Turbulent Wages? Journal of Monetary Economics (forthcoming).

Davis, S.J., and J.A. Kahn (2008). Interpreting the Great Moderation: Changes in the Volatility of Economic Activity at the Micro and Macro Levels. Journal of Economic Perspectives 22: 155-180.

Deutsches Institut für Wirtschaftsforschung (DIW) (2007). Vermögen in Deutschland wesentlich ungleicher verteilt als Einkommen. DIW Wochenbericht 74: $665-672$.

Di Giovanni, J, and A.A. Levchenko (2008). Trade Openness and Volatility. Review of Economics and Statistics (forthcoming).

Feenstra, R.C., R.E. Lipsey, H. Deng, A. C. Ma, and H. Mo (2005). World Trade Flows: 1962-2000. National Bureau of Economic Research. NBER Working Paper 11040. Cambridge MA.

Gali, J., J.D. López-Salido, and J. Vallés (2004). Rule-of Thumb Consumers and the Design of Interest Rate Rules. Journal of Money, Credit, and Banking 36: 769-763.

Gali, J., J.D. López-Salido, and J. Vallés (2007). Understanding the Effects of Government Spending on Consumption. Journal of the European Economic Association 5: 227-270.

Dew-Becker, I., and R.J. Gordon (2008). The Role of Labor Market Changes in the Slowdown of European Productivity Growth. National Bureau of Economic Research. NBER Working Paper 13840. Cambridge MA.

Gorbachev, O. (2007). Did Household Consumption Become More Volatile? Department of Economics, Columbia University. Mimeo.

Kose, M.A., E. Prasad, K. Rogoff, and S.-J. Wei (2006). Financial Globalization: A Reappraisal. International Monetary Fund. IMF Working Paper WP/06/189. Washington DC. 
Leblebicioglu, A. (2008). Financial Integration, Credit Market Imperfections and Consumption Smoothing. Journal of Economic Dynamics and Control (forthcoming).

Levchenko, A.A. (2005). Financial Liberalization and Consumption Volatility in Developing Countries. IMF Staff Papers 52: 237-259.

Lusardi, A., O.S. Mitchell (2007). Baby Boomer retirement security: The roles of planning, financial literacy, and housing wealth. Journal of Monetary Economics 54: 205-224

Mankiw, N.G., and S.P. Zeldes (1991). The Consumption of Stockholders and Non-Stockholders. Journal of Financial Economics 29: 97-112.

Occhino, F. (2004). Modeling the response of money and interest rates to monetary policy shocks: a segmented markets approach. Review of Economic Dynamics 7: 181-197.

Organisation for Economic Co-Operation and Development (OECD) (2007). OECD Employment Outlook. Chapter 3: OECD Workers in the Global Economy: Increasingly Vulnerable? Paris: 105-155.

Pesaran, M.H. (2006). Estimation and Inference in Large Heterogeneous Panels with a Multifactor Error Structure. Econometrica 74: 967-1012.

Schindler, M. (2008). Measuring Financial Integration: A New Data Set. IMF Staff Papers 56: 222-238.

Schmitt-Grohé, S., and M. Uribe (2003). Closing Small Open Economy Models. Journal of International Economics 61: 163-185.

Sitchinava, N. (2008). Trade, Technology, and Wage Inequality: Evidence from U.S. Manufacturing, 1989-2004. University of Oregon. Mimeo.

Timmer, M., M. O'Mahony, and B. van Ark (2007). The EU KLEMS Growth and Productivity Accounts: An Overview. International Productivity Monitor 14: 71-85. 


\section{Data Appendix}

The main data source is EU KLEMS. All data are freely available on the internet and can be downloaded from www.euklems.net. See Timmer et al. (2007) for details on the data definitions and original sources.

Wages: Average wages per employee are obtained by dividing total labor compensation by the number of employees in a specific category $\left(L A B / H_{-} E M P\right)$. Labor compensation by skill group is obtained by $L A B \times$ $(L A B / 100)$ for high-skilled workers and corresponding measures for mediumund low-skilled workers. Nominal values are converted into constant U.S. dollar by (i) converting values in national currency into U.S. dollar using the Summers-Heston exchange rate series, adjusting for euro conversion rates, and (ii) deflating by the U.S. output price index in each sector.

Hours worked $\left(H_{-} E M P\right)$ : Hours worked by skill group are given by $H_{-} E M P \times\left(H_{-} \bar{H} S / 100\right)$ for high-skilled workers and corresponding measures for medium- and low-skilled workers. According to Timmer et al. (2007), information on the skill levels of workers included in EU KLEMS is usually obtained from national labor force surveys, sometimes together with a earnings survey. Hence, data may not be fully comparable across countries but they should be comparable over time as well as between industries for a given country.

Total Factor Productivity (TFPva_I): TFP growth, both value-added and output-based. Output per hour growth minus capital deepening growth (= real capital growth - growth in total hours worked $\times$ capital's share in output).

International financial integration: (i) Cross-border debt assets plus liabilities / GDP, (ii) Total cross border assets plus liabilities / GDP. Source: $\{$ Lane/Milesi-Ferretti $\}$.

Domestic financial development: Deposit money bank assets / GDP. Source: \{World Bank, Financial Structures Database, November 2008 update\}.

Trade: (i) OECD Stan: Data on import-export ratios, the export share of production, and the import penetration ratio by industry, 1980-2004, for the following manufacturing sectors: Food, Textiles, Wood, Pulp \& Paper, Chemicals, Non-metallic mineral products, Based metals, Machinery, Transport equipment, (ii) World Trade Flows: Data on bilateral import volumes obtained from Feenstra et al. (2005). SITC4 industry classification codes were converted into ISIC codes (Version 3) using industry concordances kindly provided by Julian di Giovanni and used in di Giovanni and Levchenko (2008). For the years before 1990, we use West German data to match the data to EU KLEMS. 
List of countries: The EU KLEMS database contains information on $27 \mathrm{Eu}-$ ropean countries plus Japan and the United States. However, due to incomplete time series and missing observations, in particular concerning a breakdown of employment by skill, we use only the following 11 countries: $\mathrm{AUT}=$ Austria, $\mathrm{DNK}=$ Denmark, ESP $=$ Spain, FIN $=$ Finland, FRA $=$ France, GER $=$ Germany ITA $=$ Italy, JPN $=$ Japan, NLD $=$ Netherlands, $\mathrm{UK}=$ United Kingdom, USA $=$ United States-SIC based

List of industries: The EU KLEMS database contains industry-level data at different levels of aggregation. We use data at the 2-digit level, and we drop the sectors agriculture, fishing, and extra-territorial organizations due to missing and incomplete observations. Hence, we use data for the following sectors (sector codes based on NACE): $15 t 16=$ Food, Beverages and Tobacco; $\mathbf{1 7 t 1 9}=$ Textiles, Leather, and Footwear; $20=$ Wood, products of wood, and cork; 21t22 = Pulp, paper, printing and publishing; 23t25 = Chemicals, rubber, plastic, and fuels; $26=$ Other non-metallic mineral products; 27t28 = Basic metals and fabricated metals; $29=$ Machinery nec.; $30 t 33=$ Electrical and optimal equipment; 34t35 = Transport equipment; $\boldsymbol{C}=$ Mining and quarrying; $\boldsymbol{E}=$ Electricity, gas, and water supply; $\boldsymbol{F}=$ Construction; $\boldsymbol{G}=$ wholesale and retail trade; $\boldsymbol{H}=$ Hotels and restaurants; $\boldsymbol{I}=$ Transport, storage, and communications; $\boldsymbol{J}=$ Financial intermediation, $\boldsymbol{K}=$ Real estate, renting, and business activities; $\boldsymbol{L}=$ Public administration and defense, social security; $\boldsymbol{N}=$ Health and social work; $\boldsymbol{O}=$ Other services

In some countries, industry classifications have changed in the mid-1990s. Where available, the EU KLEMS database uses conversion tables provided by the national statistical offices. The change in the American classification system (from SIC87 to NAICS97) was more far-reaching than of the most recent change in the European system.

German dummy: Dummy variable equal to one for the years 1990 and 1991 for Germany to capture the unification effect.

Inflation: Change in the price level of consumption (CP) is the PPP over GDP divided by the exchange rate times 100. The PPP of GDP or any component is the national-currency value divided by the real value in international dollars. The PPP and the exchange rate are both expressed as national currency units per U.S. dollar. From Penn World Table 6.1 (PWT $6.1)$.

Energy price index: Growth in HWWI-World energy price index U.S. dollar based, $2000=100$. 
Figure 1: Volatility of Hours Worked and Wages

This figure plots the median volatility of hours worked and wages for 11 European countries, the United States, and Japan across 22 industries. Volatility is defined as the standard deviation of the growth rate of hours worked and wages over a rolling 5-year window. Unconditional volatility is derived from the growth rates of hours worked and wages. Conditional volatility is derived from the residuals of a regression of these growth rates on time-country and time-industry fixed effects and year dummies. For Figures 1c-1d, conditional volatilities have been obtained using the multifactor residual model developed by Pesaran (2006) described in the main body of the text. Volatility in $t$ is defined for the subsequent period $[t, t+4]$.

(a) Volatility of hours worked and wages ("short and wide" Panel 1, 1982-2002)
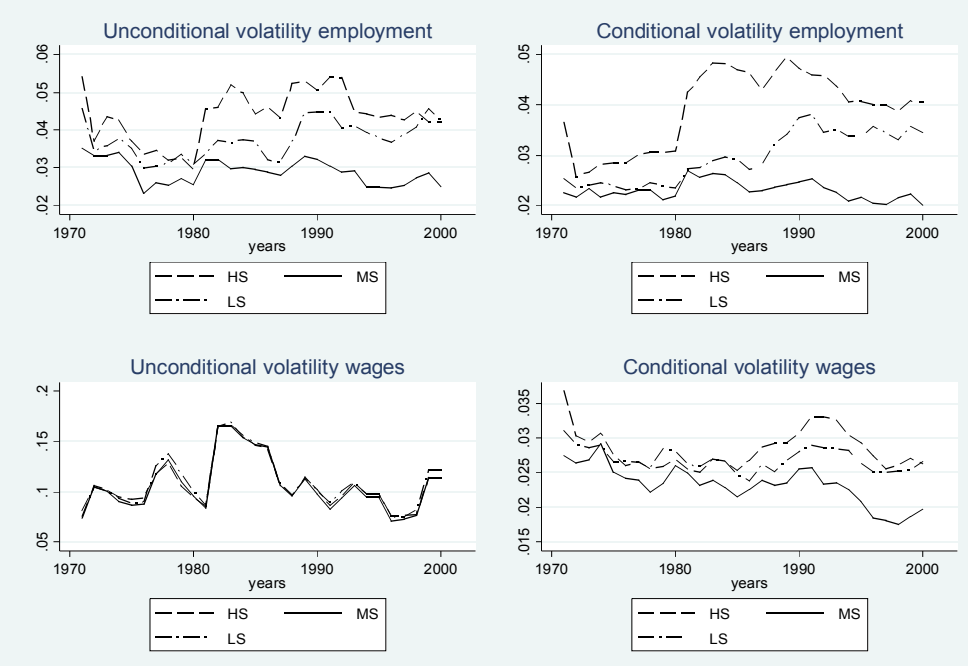

(b) Volatility of TFP ("short and wide" Panel 1, 1982-2002)
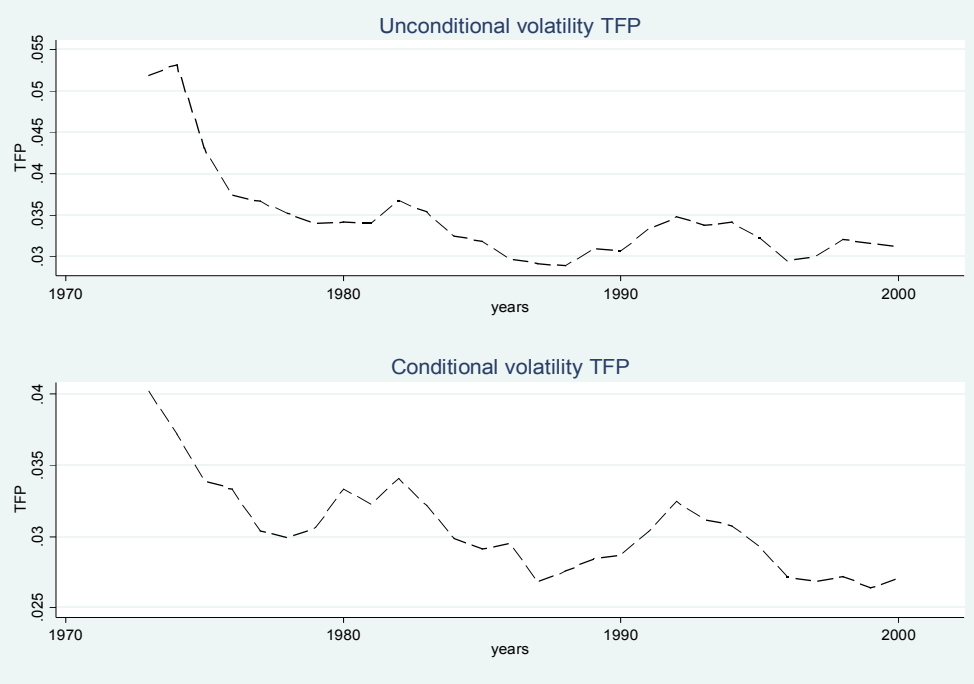
(c) Volatility of hours worked and wages ("long and narrow" Panel 2, 1970-2004)
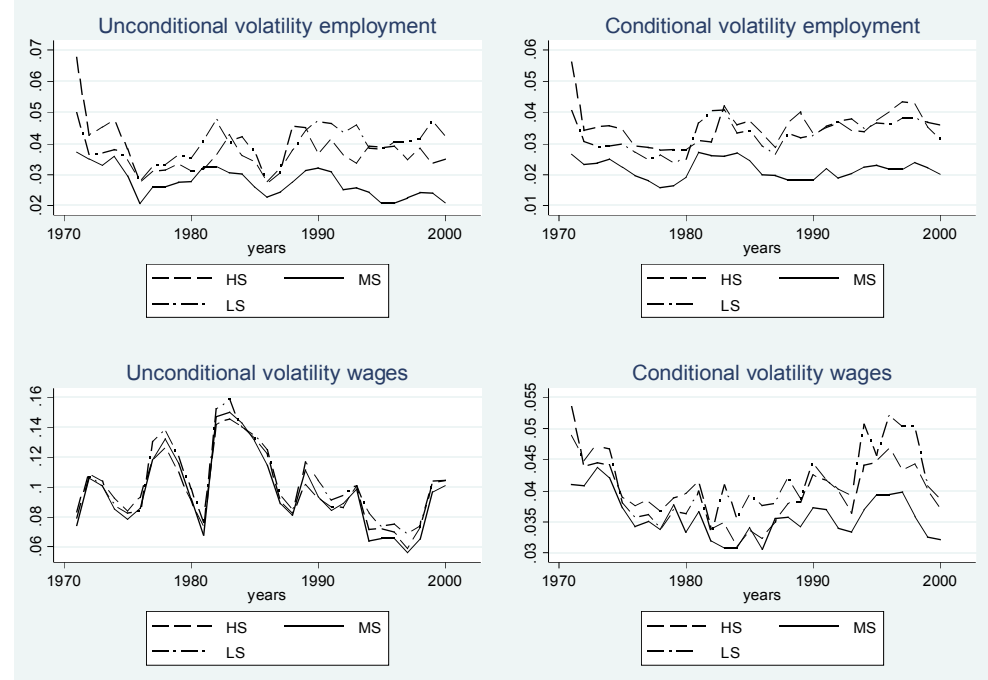

(d) Volatility of TFP ("long and narrow" Panel 2, 1970-2004)
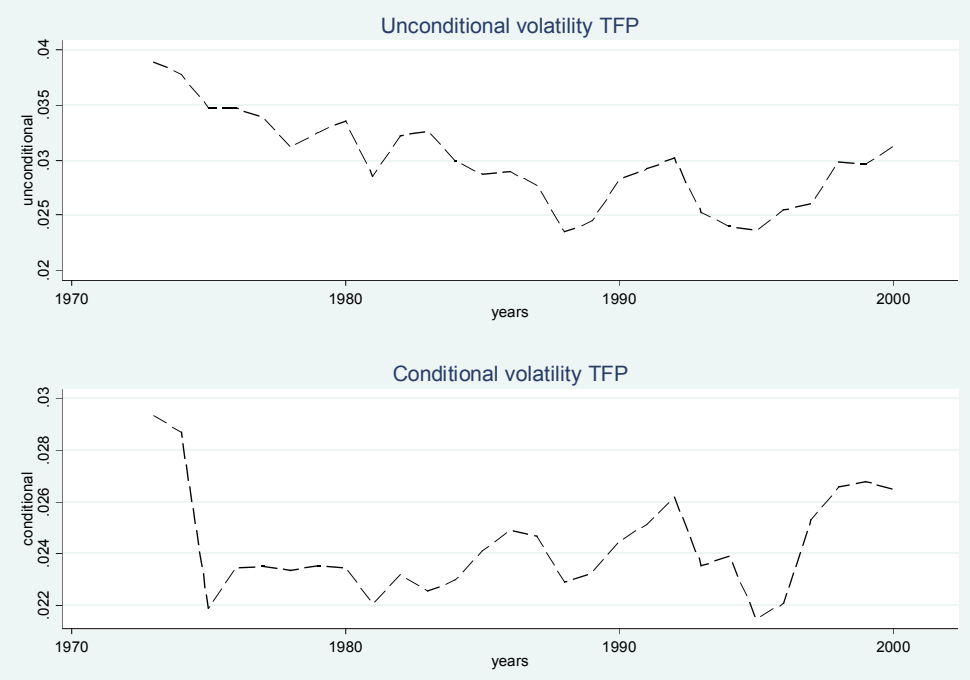
(e) Foreign debt ratio and employment shares (1970-2004)
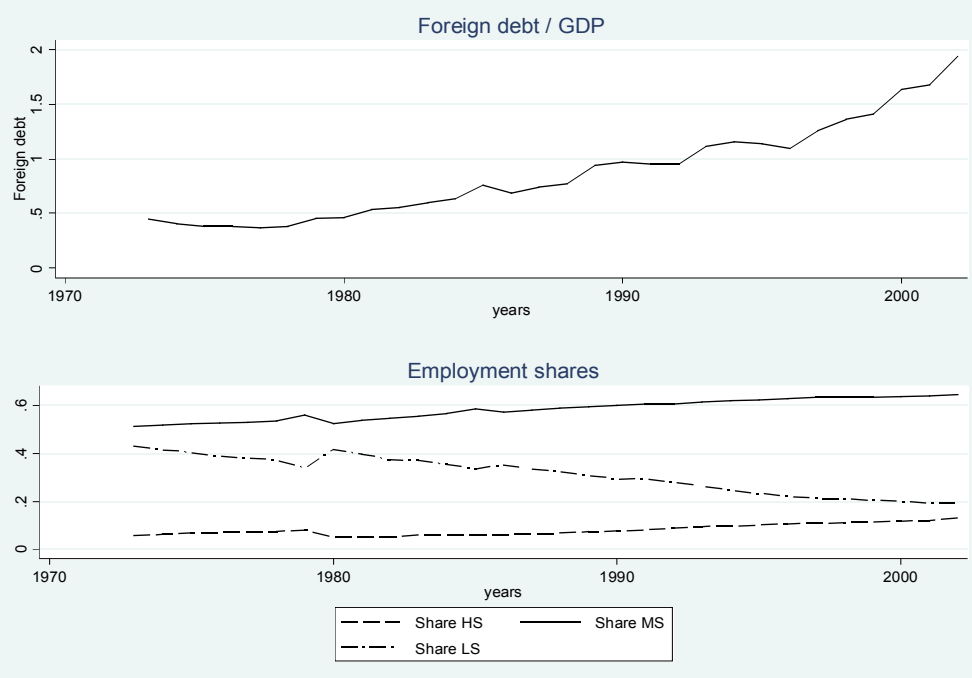
Table 1: Descriptive Statistics (Full sample)

\begin{tabular}{|l|c|c|c|c|c|}
\hline \hline Variable & Obs & Mean & Std. Dev. & Min & Max \\
\hline Unconditional volatility (5-year moving average) & & & & & \\
TFP & 6.306 & 0.042 & 0.034 & 0.002 & 0.622 \\
Employment & 6.348 & 0.028 & 0.019 & 0.002 & 0.202 \\
High-skilled employment & 6.389 & 0.061 & 0.055 & 0.002 & 0.437 \\
Medium-skilled employment & 6.394 & 0.036 & 0.029 & 0.002 & 0.310 \\
Low-skilled employment & 6.394 & 0.050 & 0.043 & 0.001 & 0.581 \\
Wages & 6.394 & 0.108 & 0.051 & 0.003 & 0.756 \\
High-skilled wages & 6.394 & 0.112 & 0.051 & 0.008 & 0.761 \\
Medium-skilled wages & 6.394 & 0.108 & 0.051 & 0.006 & 0.753 \\
Low-skilled wages & 6.394 & 0.114 & 0.051 & 0.011 & 0.766 \\
Conditional volatility (5-year moving average) & & & & & \\
TFP & 6.306 & 0.037 & 0.028 & 0.003 & 0.505 \\
Employment & 6.348 & 0.021 & 0.014 & 0.002 & 0.173 \\
High-skilled employment & 6.389 & 0.054 & 0.046 & 0.003 & 0.446 \\
Medium-skilled employment & 6.394 & 0.029 & 0.022 & 0.001 & 0.237 \\
Low-skilled employment & 6.394 & 0.040 & 0.034 & 0.003 & 0.462 \\
Wages & 6.394 & 0.026 & 0.026 & 0.002 & 0.546 \\
High-skilled wages & 6.394 & 0.036 & 0.029 & 0.003 & 0.539 \\
Medium-skilled wages & 6.394 & 0.029 & 0.027 & 0.001 & 0.552 \\
Low-skilled wages & 6.394 & 0.034 & 0.029 & 0.002 & 0.547 \\
\hline \hline
\end{tabular}




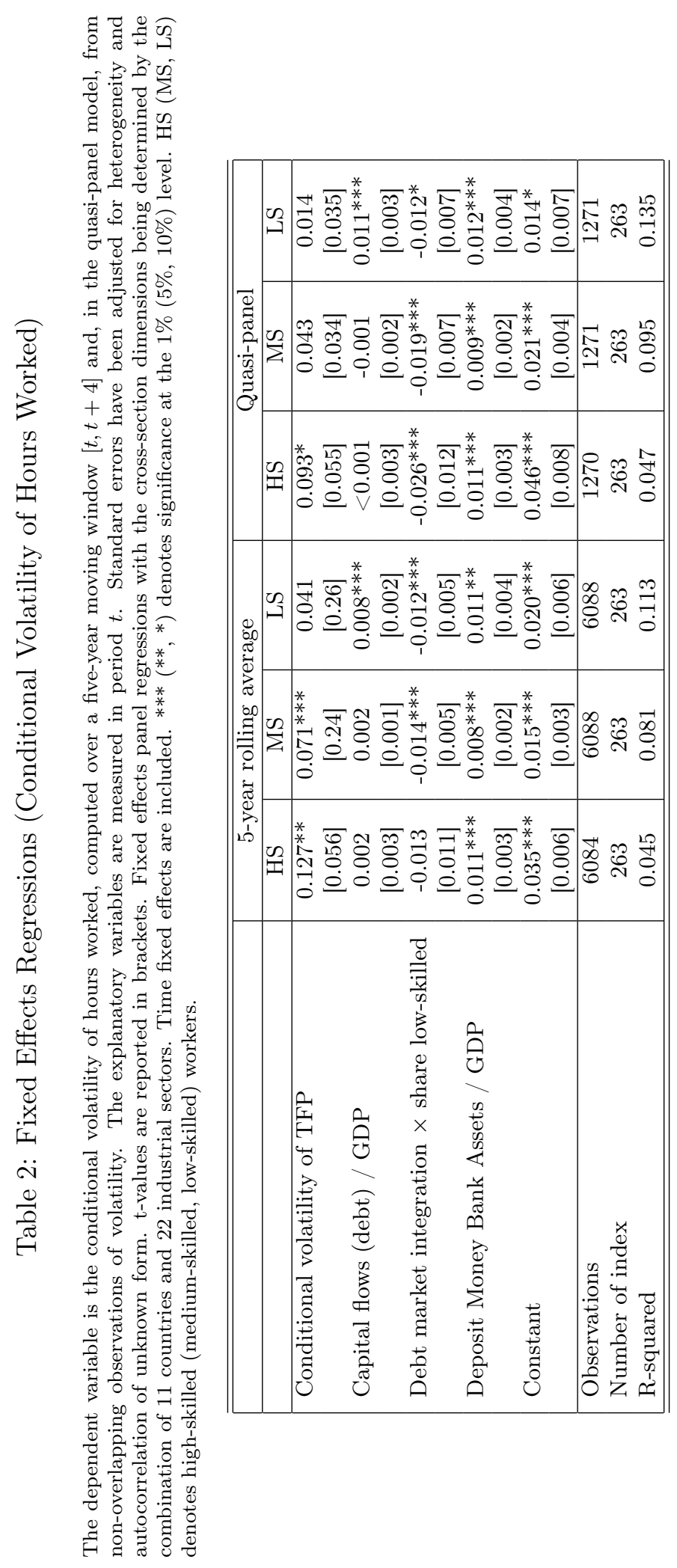




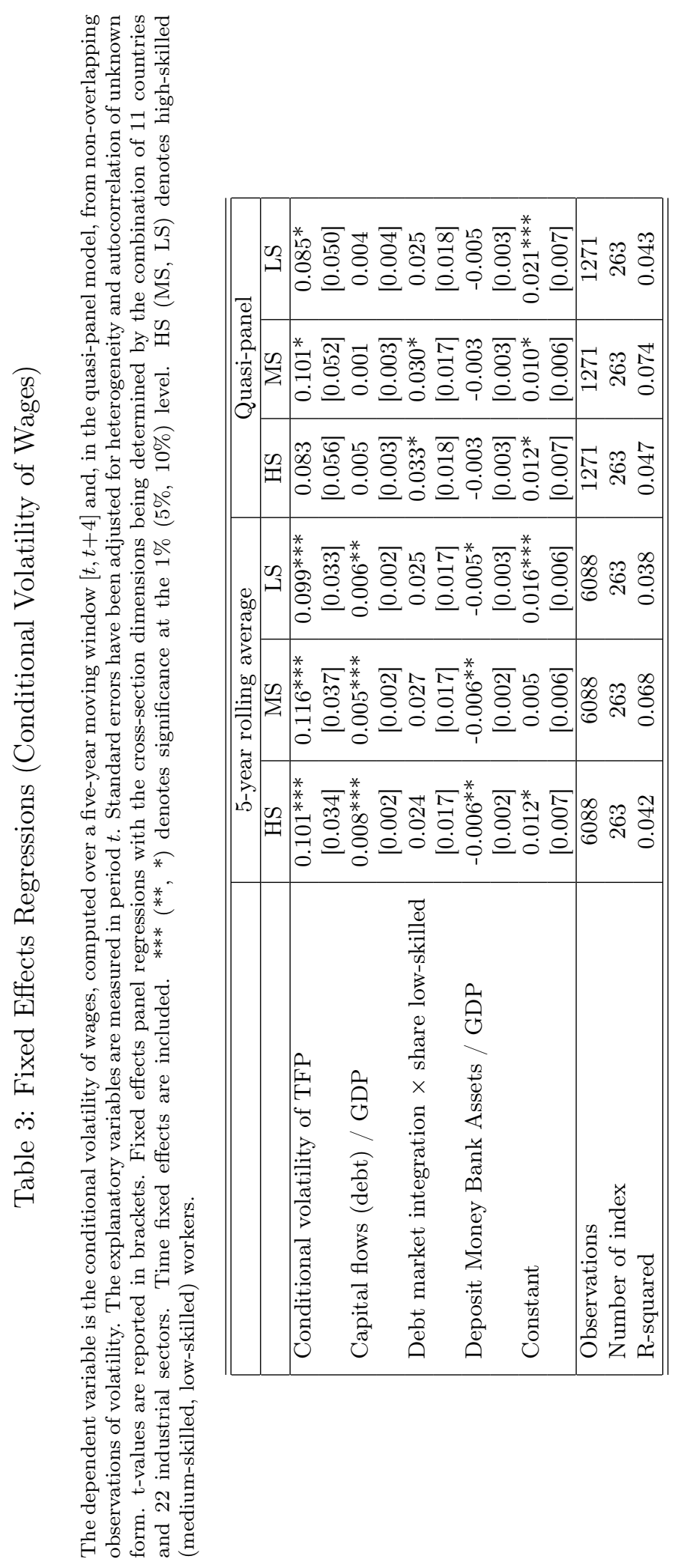




\section{CESifo Working Paper Series}

for full list see www.cesifo-group.org/wp

(address: Poschingerstr. 5, 81679 Munich, Germany, office@cesifo.de)

2601 Ana B. Ania and Andreas Wagener, The Open Method of Coordination (OMC) as an Evolutionary Learning Process, April 2009

2602 Simon Gächter, Daniele Nosenzo, Elke Renner and Martin Sefton, Sequential versus Simultaneous Contributions to Public Goods: Experimental Evidence, April 2009

2603 Philippe Jehiel and Andrew Lilico, Smoking Today and Stopping Tomorrow: A Limited Foresight Perspective, April 2009

2604 Andreas Knabe, Steffen Rätzel, Ronnie Schöb and Joachim Weimann, Dissatisfied with Life, but Having a Good Day: Time-Use and Well-Being of the Unemployed, April 2009

2605 David Bartolini and Raffaella Santolini, Fiscal Rules and the Opportunistic Behaviour of the Incumbent Politician: Evidence from Italian Municipalities, April 2009

2606 Erkki Koskela and Jan König, Can Profit Sharing Lower Flexible Outsourcing? A Note, April 2009

2607 Michel Beine, Frédéric Docquier and Çağlar Özden, Diasporas, April 2009

2608 Gerd Ronning and Hans Schneeweiss, Panel Regression with Random Noise, April 2009

2609 Adam S. Booij, Bernard M.S. van Praag and Gijs van de Kuilen, A Parametric Analysis of Prospect Theory's Functionals for the General Population, April 2009

2610 Jeffrey R. Brown, Julia Lynn Coronado and Don Fullerton, Is Social Security Part of the Social Safety Net?, April 2009

2611 Ali Bayar and Bram Smeets, Economic, Political and Institutional Determinants of Budget Deficits in the European Union, April 2009

2612 Balázs Égert, The Impact of Monetary and Commodity Fundamentals, Macro News and Central Bank Communication on the Exchange Rate: Evidence from South Africa, April 2009

2613 Michael Melvin, Christian Saborowski, Michael Sager and Mark P. Taylor, Bank of England Interest Rate Announcements and the Foreign Exchange Market, April 2009

2614 Marie-Louise Leroux, Pierre Pestieau and Gregory Ponthiere, Should we Subsidize Longevity?, April 2009

2615 Ronald MacDonald, Lukas Menkhoff and Rafael R. Rebitzky, Exchange Rate Forecasters' Performance: Evidence of Skill?, April 2009 
2616 Frederick van der Ploeg and Steven Poelhekke, The Volatility Curse: Revisiting the Paradox of Plenty, April 2009

2617 Axel Dreher, Peter Nunnenkamp, Hannes Öhler and Johannes Weisser, Acting Autonomously or Mimicking the State and Peers? A Panel Tobit Analysis of Financial Dependence and Aid Allocation by Swiss NGOs, April 2009

2618 Guglielmo Maria Caporale, Roman Matousek and Chris Stewart, Rating Assignments: Lessons from International Banks, April 2009

2619 Paul Belleflamme and Martin Peitz, Asymmetric Information and Overinvestment in Quality, April 2009

2620 Thomas Dohmen, Armin Falk, David Huffman and Uwe Sunde, Are Risk Aversion and Impatience Related to Cognitive Ability?, April 2009

2621 Yin-Wong Cheung and Xingwang Qian, The Empirics of China's Outward Direct Investment, April 2009

2622 Frédérique Bec and Christian Gollier, Assets Returns Volatility and Investment Horizon: The French Case, April 2009

2623 Ronnie Schöb and Marcel Thum, Asymmetric Information Renders Minimum Wages Less Harmful, April 2009

2624 Martin Ruf and Alfons J. Weichenrieder, The Taxation of Passive Foreign Investment Lessons from German Experience, April 2009

2625 Yao Li, Borders and Distance in Knowledge Spillovers: Dying over Time or Dying with Age? - Evidence from Patent Citations, April 2009

2626 Jim Malley and Ulrich Woitek, Technology Shocks and Aggregate Fluctuations in an Estimated Hybrid RBC Model, April 2009

2627 Jin Cao and Gerhard Illing, Endogenous Systemic Liquidity Risk, April 2009

2628 Thiess Buettner and Bjoern Kauder, Revenue Forecasting Practices: Differences across Countries and Consequences for Forecasting Performance, April 2009

2629 Håkan Selin, The Rise in Female Employment and the Role of Tax Incentives - An Empirical Analysis of the Swedish Individual Tax Reform of 1971, April 2009

2630 Nick Johnstone and Ivan Hascic, Environmental Policy Design and the Fragmentation of International Markets for Innovation, April 2009

2631 Spiros Bougheas, Richard Kneller and Raymond Riezman, Optimal Education Policies and Comparative Advantage, April 2009

2632 Jay Pil Choi and Heiko Gerlach, Multi-Market Collusion with Demand Linkages and Antitrust Enforcement, April 2009 
2633 Thor O. Thoresen, Income Mobility of Owners of Small Businesses when Boundaries between Occupations are Vague, April 2009

2634 Guido Schwerdt and Amelie C. Wuppermann, Is Traditional Teaching really all that Bad? A Within-Student Between-Subject Approach, April 2009

2635 Kurt R. Brekke, Luigi Siciliani and Odd Rune Straume, Hospital Competition and Quality with Regulated Prices, April 2009

2636 Peter Diamond, Taxes and Pensions, April 2009

2637 Shoshana Grossbard, How "Chicagoan" are Gary Becker's Economic Models of Marriage?, May 2009

2638 Roland Strausz, Regulatory Risk under Optimal Incentive Regulation, May 2009

2639 Holger Zemanek, Ansgar Belke and Gunther Schnabl, Current Account Imbalances and Structural Adjustment in the Euro Area: How to Rebalance Competitiveness, May 2009

2640 Harald Hau and Marcel Thum, Subprime Crisis and Board (In-)Competence: Private vs. Public Banks in Germany, May 2009

2641 Martin Halla, Mario Lackner and Friedrich G. Schneider, An Empirical Analysis of the Dynamics of the Welfare State: The Case of Benefit Morale, May 2009

2642 Balázs Égert, Infrastructure Investment in Network Industries: The Role of Incentive Regulation and Regulatory Independence, May 2009

2643 Christian Gollier, Expected Net Present Value, Expected Net Future Value, and the Ramsey Rule, May 2009

2644 Sören Blomquist and Håkan Selin, Hourly Wage Rate and Taxable Labor Income Responsiveness to Changes in Marginal Tax Rates, May 2009

2645 Dominique Demougin, Oliver Fabel and Christian Thomann, Implicit vs. Explicit Incentives: Theory and a Case Study, May 2009

2646 Francesco C. Billari and Vincenzo Galasso, What Explains Fertility? Evidence from Italian Pension Reforms, May 2009

2647 Kjell Arne Brekke, Karen Evelyn Hauge, Jo Thori Lind and Karine Nyborg, Playing with the Good Guys - A Public Good Game with Endogenous Group Formation, May 2009

2648 Guglielmo Maria Caporale and Luis A. Gil-Alana, Multi-Factor Gegenbauer Processes and European Inflation Rates, May 2009

2649 Henning Bohn, A Static Model for Voting on Social Security, May 2009

2650 Markus Haavio and Kaisa Kotakorpi, The Political Economy of Sin Taxes, May 2009 
2651 Augusto de la Torre, María Soledad Martínez Pería and Sergio L. Schmukler, Drivers and Obstacles to Banking SMEs: The Role of Competition and the Institutional Framework, May 2009

2652 Tobias Lindhe and Jan Södersten, Dividend Taxation, Share Repurchases and the Equity Trap, May 2009

2653 Assaf Razin and Edith Sand, Migration-Regime Liberalization and Social Security: Political-Economy Effect, May 2009

2654 Yin-Wong Cheung and Hiro Ito, A Cross-Country Empirical Analysis of International Reserves, May 2009

2655 Bart Cockx and Bruno Van der Linden, Flexicurity in Belgium. A Proposal Based on Economic Principles, May 2009

2656 Michael Melvin, Lukas Menkhoff and Maik Schmeling, Exchange Rate Management in Emerging Markets: Intervention via an Electronic Limit Order Book, May 2009

2657 Susanne Neckermann, Reto Cueni and Bruno S. Frey, What is an Award Worth? An Econometric Assessment of the Impact of Awards on Employee Performance, May 2009

2658 Steven Brakman, Harry Garretsen and Charles van Marrewijk, Economic Geography within and between European Nations: The Role of Market Potential and Density across Space and Time, May 2009

2659 Giovanni Facchini and Cecilia Testa, Reforming Legislatures: Is one House better than two?, May 2009

2660 Carsten Kowalczyk and Raymond Riezman, Trade Agreements, May 2009

2661 Oliver Falck, Stephan Heblich and Elke Luedemann, Identity and Entrepreneurship, May 2009

2662 Christian Lessmann and Gunther Markwardt, One Size Fits All? Decentralization, Corruption, and the Monitoring of Bureaucrats, May 2009

2663 Felix Bierbrauer, On the Legitimacy of Coercion for the Financing of Public Goods, May 2009

2664 Alessandro Cigno, Agency in Family Policy: A Survey, May 2009

2665 Claudia M. Buch and Christian Pierdzioch, Low Skill but High Volatility?, May 2009 